\author{
Milan SÁGA Jr. ${ }^{1}$, Martin BOHUŠÍ́K ${ }^{1}$ \\ Supervisor: Ivan KURIC ${ }^{2}$ \\ DOI: https://doi.org/10.53052/9788366249844.18
}

\title{
OCENA RYZYKA MASZYNY
}

\begin{abstract}
Streszczenie: W artykule skupiono się na ocenie ryzyka maszyn nieokreślonych. Opiera się na aktualnej normie ISO. W pierwszej części artykułu znajduje się opis ocenianego systemu. Następnie wyjaśnia się procedurę oceny, częstotliwość i czas trwania zagrożenia, możliwość uniknięcia niebezpieczeństwa lub ograniczenia szkód oraz określa poziom możliwego urazu. Na podstawie tych danych możemy określić stopień zagrożenia. Poniższa sekcja dotyczy konkretnych zagrożeń, które pojawiają się podczas działania dowolnych maszyn. Te zagrożenia należy ocenić. W artykule skupiono się również na piktogramach, które są również wykorzystywane w ocenie ryzyka.
\end{abstract}

Słowa kluczowe: maszyny, ocena ryzyka, zarządzanie ryzykiem..

\section{RISK ASSESSMENT OF MACHINERY}

\begin{abstract}
The article focuses the risk assessment of indeterminate machinery. It based on the current ISO standard. The description of the assessed system is given in the first part of the paper. Then the following aspects are explained: the evaluation procedure, frequency and duration of the threat, the possibility of avoiding danger or limiting damage. Moreover, the level of possible injury is determined. From this data, we can determine the severity of the threat. The following section deals with the specific risks that arise in the operation of any machines. These risks need to be assessed. The article also focuses on pictograms, which are also used in risk assessment.
\end{abstract}

Keywords: Machinery, Risk assessment, Risk management..

\section{Risk assessment of machinery}

The existing dangers to which employees are exposed during operation or maintenance can be identified and reduced using a systematic risk assessment tailored for each device's particular requirements.

\footnotetext{
${ }^{1}$ Ing., University of Žilina, Faculty of Mechanical Engineering, Department of Automation and Production Systems, e-mail:milan.saga2@fstroj.uniza.sk,martin.bohusik@fstroj.uniza.sk ${ }^{2}$ prof. Dr. Ing., University of Bielsko-Biala, Faculty of Mechanical Engineering and Computer Science, Department of Industrial Engineering: kuric.ivan@gmail.com
} 


\subsection{Determination of the required performance level (PLr)}

It deals with risk reduction by the safety parts of the control system under consideration. This method only contributes to the estimation of risk reduction and aims to provide guidance to the designer and standard setter in determining the $\mathrm{PL}_{\mathrm{r}}$, for each safety function it performs.

The risk assessment assumes the situation before taking action on the intended safety function. Risk mitigation by other technical measures that are independent of the control system (for example, mechanical protection devices) or additional safety functions may be determined to determine the PLr, the intended safety function. The severity of the injury (indicated by the letter $\mathrm{S}$ ) is relatively easy to estimate (eg cut, amputation, fatal injury). In terms of frequency of occurrence, ancillary parameters are used to improve risk estimation. These parameters are:

- frequency and duration of the threat $(\mathrm{F}) \mathrm{a}$

- possibility of avoiding danger or limiting damage $(\mathrm{P})$

Experience has shown that these parameters can be combined as seen in the figure, with the risk ranging from low to high. It should be emphasized that this is a qualitative process that only results in a risk assessment. [1] [2] [3]

\subsection{Degree of severe injury $S 1$ and $S 2$}

In estimating the risk arising on failure of the safety function it is considered only slight injuries (normally reversible), serious injuries (normally irreversible) and death. When determining S1 and S2, the normal consequences of the accident and the healing process must be taken into account.

S1 - bruising or laceration without complications

S2 - amputation or death [1] [2] [3]

\subsection{Frequency or duration threat $\mathrm{F} 1$ and $\mathrm{F} 2$}

The generally valid time to be selected for parameters F1 and F2 cannot be speci-fied. However, the following explanation could facilitate the correctness of the deci-sion when there are doubts.

F2 must be chosen if the person is frequently or constantly endangered. It is irrelevant whether the same persons or different persons are exposed to successive threats, for example when using lifts. The frequency of occurrence of parameters must be selected according to the frequency and duration of access to the threat.

If the designer knows the requirement for the safety function, the frequency of occurrence and duration of this requirement can be chosen instead of the frequency of occurrence and duration of access to the threat. In this part of ISO 13849, the frequency of occurrence of a safety function is considered more than once a year.

The duration of the hazard must be assessed on the basis of an average value that can be determined in relation to the overall use of the equipment. For example, if it is necessary to reach regularly between the tools of the machine during its cycle in order to complete and move the workpieces, F2 must be selected. If such an approach is only necessary occasionally, F1 must be selected. [1] [2] [3] 


\subsection{Possibility to avoid threat $P 1$ and $P 2$}

It is very important to know whether a threat situation can be identified and avoided before an accident occurs. For example, serious consideration must be given to whether the threat can be directly identified by physical characteristics or only by technical means, such as indicators. Other important aspects that influence the choice of the P parameter are, for example:

- operation with or without supervision,

- operation management by experts or non-professionals,

- $\quad$ speed at which the risk increases (for example fast or slow),

- the possibility of preventing threats (such as leaks),

- $\quad$ practical safety experience relevant to the process.

If a hazard occurs, only $\mathrm{P} 1$ must be selected if there is a real possibility to prevent the accident or significantly reduce its effect. P2 must only be selected if there is almost no possibility of preventing danger.

The figure below provides instructions for determining the safety PLr, which depends on the risk assessment. This scheme must be considered for each safety function. The risk assessment method is based on ISO 14121 and must be used in accordance with ISO 12100-1. [1] [2] [3]

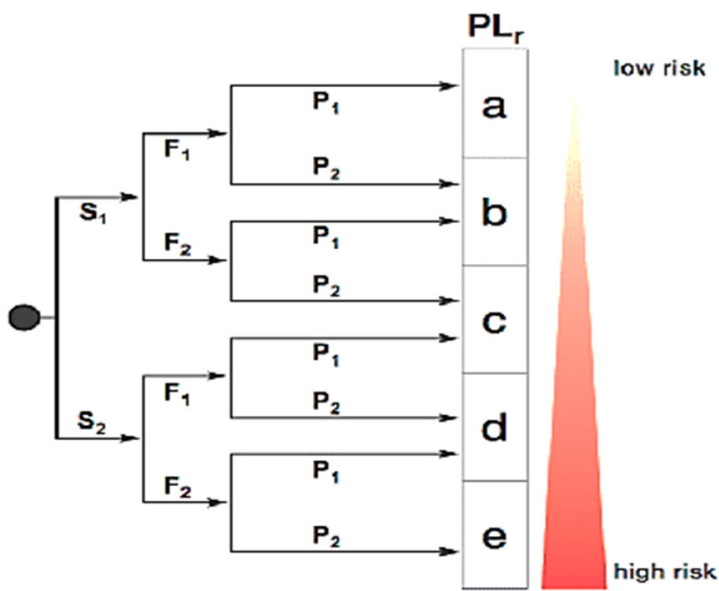

Figure 1. Risk graph for determining the required performance level for a safety function [1]

\section{Risk management}

The international standard which provides general procedures for risk manage-ment is ISO 31000: 2018 Risk management. The Slovak version of the standard is derived from it - STN ISO 31000: 2019 Risk management - instructions. In this standard lists are the stages of the risk management process shown in FIG. 2. The stages of the risk 
management process are following activities and outputs and final-ly represent a cycle. This process is an integral part of business management, and must be adapted to current conditions in activity and corporate culture. [6] [7] [3]

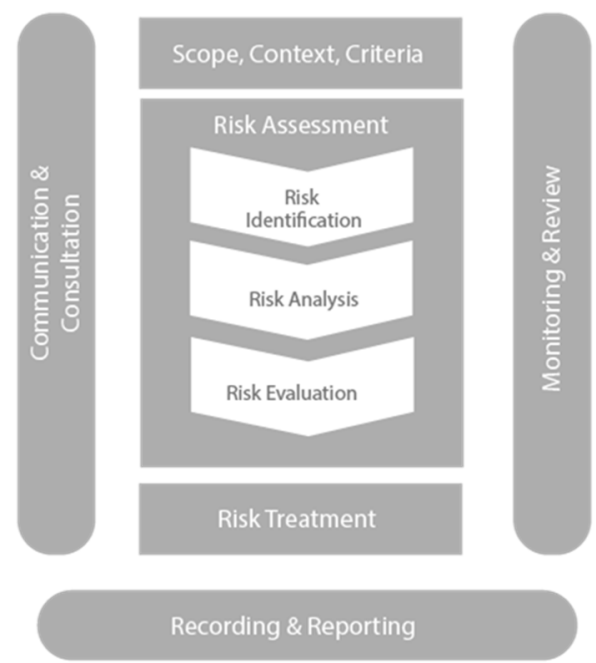

Figure 2. Process of risk management (Modified from: [8])

\subsection{Breakdown and some sources of risks in the risk assessment of machinery}

1. Mechanical hazards

1.1. Crushing hazard

1.2. Shear hazard

1.3. Danger of cutting or detachment

2. Electrical hazard

2.1. Contact of people with live parts (direct contact)

2.2. Contact of persons with live parts as a result of poor conditions, in particular breach of insulation with live parts (indirect contact)

2.3. Overcurrent

3. Thermal hazard

3.1. Burns, scalds and other injuries caused by contact with persons with extremely hot or cold objects, material, flame or explosion and radiation from a hot surface

3.2. Damage to health by hot or cold working environment

4. Noise hazard

4.1. Hearing impairment (deafness), other physiological damage (eg loss of balance, loss of consciousness, feeling tired, mental disorders, loss of attention)

4.2. Interference of speech, sound signals, etc.

5. Vibration hazard

5.1. Use of hand tools, various nervous and vascular diseases

5.2. Vibrations transmitted to the whole body, especially in an unsuitable posture 
6. Radiation hazard

6.1. Low frequency and high frequency and microwave radiation

6.2. X-rays and gamma rays

6.3. Laser

7. Danger from materials and substances (and their basic components)

7.1. Risk of contact with or inhalation of harmful gases, mists, vapors, smoke and dust

7.2. Risk of fire or explosion

7.3. Biological and microbiological hazards (viral or bacterial)

8. Ergonomic hazard

8.1. Improper posture and increased exertion

8.2. Failure to conform to the anatomy of the hand, upper limb and leg, lower limb

9. Hazards associated with the environment in which the machine is used

9.1. Inadequate / unsuitable local lighting

9.2. Mental overload or underestimation, stress

9.3. Improper design and placement of display units

10. A combination of threats

10.1. Unexpected start, unexpected course, (overshoot), speed (or similar failure)

10.2. Neglect of personal protective equipment

10.3. Faults, control system failure

10.4. External influence on electrical equipment

10.5. Software or operating errors

10.6. Inability to stop the machine under the most suitable conditions [3]
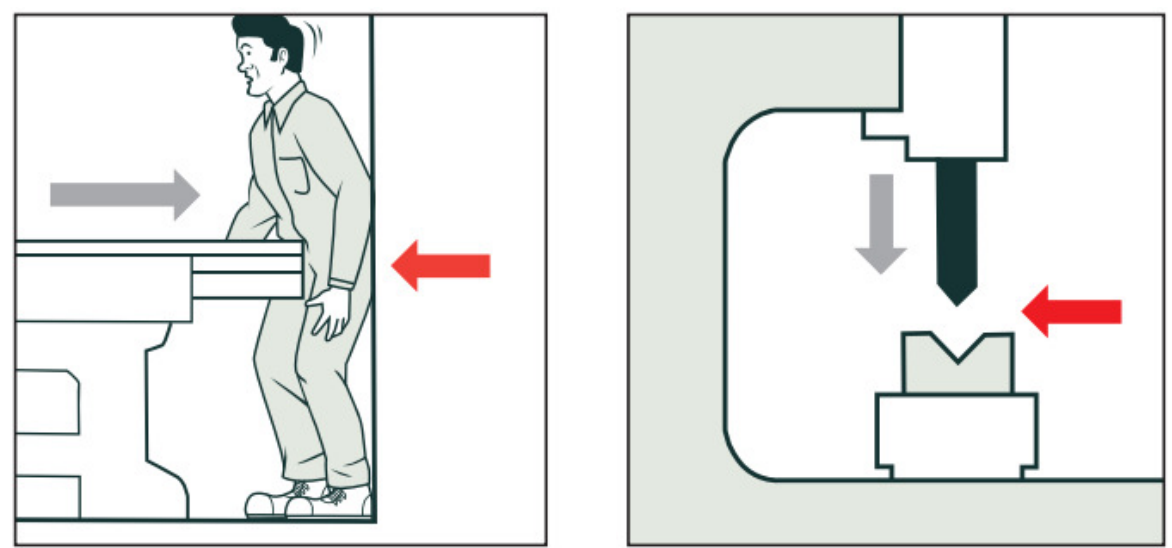

Figure 3. Examples of crushing hazards [10] 


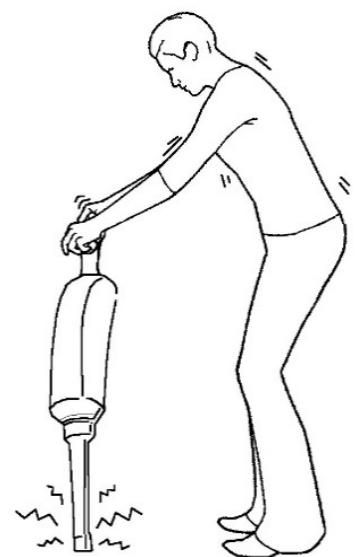

Figure 4. Example of vibrations transmitted to the whole body, especially in an unsuitable posture [11]

\section{Risk reduction}

Risk reduction can be achieved by eliminating the hazards or by individually or simultaneously reducing each of the two elements that determine the associated risk:

- Severity of damage from the considered danger,

- The likelihood of this damage [3]

\section{Design measures}

Design measures for self-safety eliminate hazards or reduce associated risks by appropriate selection of the design characteristics of the machine itself or the interaction between exposed persons and the machine. [3]

\section{Precautions or additional measures}

When considering intended use and foreseeable misuse, adequate safety protection and additional protective measures may be used to reduce the risk if the hazard cannot be eliminated or its associated risk can be sufficiently reduced by the use of self-safety design measures. [3]

\section{Usage information}

If, despite design measures to ensure one's own safety, despite safety protection and the adoption of additional protective measures, risks remain, then residual risks must be identified in the use information. Usage information must include

- Operating procedures for the use of machines that take into account the expected capabilities of the persons using the machine,

- $\quad$ Recommended safety work procedures for residual risk at various stages of the machine's life, 
- A description of any recommended personal protective equipment, including details of their use and any training in their use.

Information on use must not be a substitute for the correct application of design measures for personal safety, security protection or additional measures. [3]

\subsection{Pictograms}

Safety labels are a key part of the information on the use of providing machine manufacturers to users and are often the only information that many users can see. This makes the design and location of safety labels crucial to their effectiveness. Insufficient use of safety labels poses the same risk as excessive use of safety labels. Machine manufacturers and users often choose general labels that are readily available from catalogs, and lack the opportunity to design labels that are specific to the machine and the risk. [9]

Table 1. Example of pictograms which can be used in risk assessment of machinery [9]

Meaning of the brand
Caution, danger of being pulled in
Caution, danger of crushing
Attention flammable liquid
Hand protection command
Cansed

\section{Conclusion}

The article focuses on the risk assessment of machinery. The relevant standards are used in the article, they are: ISO 12100-1Safety of machinery. General principles for design. Risk assessment and risk reduction, which is derived on the basis of ISO 
14121-1 Safety of machinery. Risk assessment. Part 1: Principles, the article also mentions the standard STN ISO 31000 Risk management. Guidelines. This contribution may be appropriate to guide procedures in the risk assessment of machinery.

\section{LITERATURE}

1. STN EN ISO 13849-1, Safety of machinery - Safety-related parts of control systems - Part 1: General principles for design, 2016.

2. STN EN ISO 14121-1, Safety of machinery. Risk assessment. Part 1: Principles, 2008

3. STN EN ISO 12100, Safety of machinery. General principles for design.Risk assessment and risk reduction, 2011

4. ISO 31000, Risk management, 2018

5. STN ISO 31000, Risk management. Guidelines, 2019

6. BUGANOVÁ K. at al.: Manažment rizika v podniku. University of Zilina /EDIS, 2012

7. BUGANOVÁ K., ŠIMÍČKOVÁ J.: Zvyšovanie konkurencieschopnosti podnikov prostredníctvom implementácie manažmentu rizík v kontexte koncepcie industry 4.0. University of Zilina, Faculty of Safety Engineering, Department of Crisis Management, 2019

8. $\quad$ BROWN J.: Enterprise Risk Management, 2019

9. Nariadenie vlády Slovenskej republiky o požiadavkách na zaistenie bezpečnostného a zdravotného označenia pri práci č. 387/2006 Z. z., 2006

10. Safe Use of Machinery. New Zealand Government, 2014

11. Physical Hazards. The Ontario Council for Technology, 